\title{
Isolasi Bakteri Pendegradasi Mimosin Asal Rumen Sapi dan Domba yang Diberi Daun Lamtoro dan Pengaruhnya pada Karakteristik Fermentasi In Vitro
}

\author{
S. Suharti*, W. Alwi, K. G. Wiryawan \\ Departemen Ilmu Nutrisi dan Teknologi Pakan, Fakultas Peternakan, Institut Pertanian Bogor
}

(IPB University), Bogor, Indonesia 16680

\begin{abstract}
ABSTRAK
Penelitian ini bertujuan untuk mengisolasi bakteri pendegradasi mimosin dari cairan rumen domba dan sapi yang diberi pakan mengandung daun lamtoro dan menganalisis pengaruh inokulasi bakteri pendegradasi mimosin pada karakteristik fermentasi rumen secara in vitro. Tahap pertama adalah isolasi bakteri pendegradasi mimosin dari cairan rumen domba yang diberi pakan mengandung daun lamtoro 30\% dan dari rumen sapi Bali di Sumbawa yang diberi pakan daun lamtoro $100 \%$. Tahap kedua adalah inokulasi bakteri pendegradasi mimosin pada fermentasi in vitro dengan substrat mengandung daun lamtoro. Rancangan yang digunakan pada percobaan in vitro adalah rancangan acak kelompok pola faktorial dengan 2 faktor. Pengelompokan berdasarkan waktu pengambilan cairan rumen. Faktor pertama terdiri dari 3 taraf daun lamtoro yaitu 0, 30, dan $60 \%$ dalam ransum. Faktor kedua terdiri dari 2 inokulasi pendegradasi mimosin yaitu dengan dan tanpa inokulasi bakteri pendegradasi mimosin. Peubah yang diamati adalah populasi bakteri dan protozoa, nilai $\mathrm{pH}$, konsentrasi $\mathrm{NH}_{3}$, produksi volatile fatty acid (VFA), kecernaan bahan kering (KcBK) dan kecernaan bahan organik (KcBO). Hasil penelitian ditemukan 2 isolat bakteri pendegradasi mimosin dari rumen domba dan 3 isolat rumen sapi Bali. Kelima isolat tersebut mempunyai kemiripan dengan Streptococcus sp. Hasil uji in vitro menunjukkan tidak ada interaksi antara taraf pemberian daun lamtoro dengan inokulasi bakteri pendegradasi mimosin pada fermentasi rumen. Inokulasi bakteri pendegradasi mimosin dapat meningkatkan konsentrasi $\mathrm{NH}_{3}$ dan cenderung memperbaiki produksi VFA dibandingkan dengan perlakuan tanpa inokulasi bakteri. Nilai $\mathrm{pH}$, KcBK dan KcBO tidak berbeda antar perlakuan. Kesimpulan yang dapat diambil adalah inokulasi bakteri pendegradasi mimosin dapat menstimulasi fermentasi rumen secara in vitro.
\end{abstract}

Kata kunci: Lamtoro (Leucaena leucochepala), Bakteri pendegradasi mimosin, Domba, Fermentasi rumen

\section{Isolation of Mimosine-degrading Bacteria from Sheep and Cattle That Fed Leucaena Leaves and It's Effect on In vitro Fermentation Characteristics}

\begin{abstract}
This research aimed to isolate mimosine-degrading bacteria obtained from rumen liquid of sheep and cattle that fed diet containing Leucaena leaves and to analyze the effect of mimosine-degrading bacteria inoculation on rumen fermentation characteristics in vitro. The first stage was the isolation of mimosine-degrading bacteria from rumen sheep fed Leucaena leaf meal up to 30\% and Bali cattle fed with Leucaena leaves 100\%. The second stage was inoculation of mimosine-degrading bacteria in the rumen fermentation in vitro. The used design was factorial randomized block design consisted of 2 factors and 3 replications. The first factor was the level of Leucaena consisted of 0, 30, and 60\% of the total ration. The second factor was mimosine-degrading bacteria inoculation (with or without inoculation). The observed variables were $\mathrm{pH}$ value, $\mathrm{NH}_{3}$ concentration, total volatile fatty acid (VFA), dry and organic matter digestibility, protozoal and bacterial population. The results showed that there were 2 isolates from the rumen of sheep and 3 isolates from the rumen of cattle that can degrade mimosine. Based on morphological characteristics, these had similarities with Streptococcus sp. In the in vitro fermentation, there was no interaction between inoculations of mimosine-degrading bacteria on all variables observed. Inoculation of mimosine-degrading bacteria increased ( $p<0.05) \mathrm{NH}_{3}$ concentration up to $9.30 \mathrm{mM}$ and tend to improved VFA production up to $82.89 \mathrm{mM}$. pH value, dry, and organic matter digestibility were similar among treatments. In conclusion, the inoculation of mimosine-degrading bacteria has an advantage effect on rumen fermentation in the ration contain Leucaena leaf meal.
\end{abstract}

Keywords: Lamtoro (Leucaena leucochepala), Mimosine-degrading bacteria, Sheep, Rumen fermentation

\section{PENDAHULUAN}

Salah satu strategi untuk mengatasi permasalahan pakan adalah penggunaan tanaman legum pohon sebagai pakan utama ternak seperti daun lamtoro (Leucaena leucochepala). Tanaman lamtoro sudah dikenal luas masyarakat Indonesia karena bisa ditanam di berbagai tipe lahan bahkan di lahan marginal. Daun lamtoro sangat berpotensi sebagai

\footnotetext{
*Penulis Korespondensi: Sri Suharti

Alamat: J1. Agatis Kampus Fapet IPB Darmaga, Bogor16680

E-mail: sri_suharti@apps.ipb.ac.id
}

hijauan pakan sumber protein karena mengandung protein yang cukup tinggi (20-31\%) yang melebihi kandungan protein rumput Alfalfa yang hanya 14,83\% (Zayed et al., 2014). Namun demikian, daun lamtoro juga mengandung senyawa antinutrisi yang cukup toksik dan mengganggu pertumbuhan ternak yaitu mimosin (Ghosh dan Bandyopadhyay, 2007), dengan rataan antara 1,40-7,19 g/100 g bahan kering (D'Mello, 2000). Struktur mimosin mempunyai kemiripan dengan asam amino tirosin (Oppenheim et al., 2000), sehingga tubuh ternak yang mengkonsumsi daun lamtoro akan mengenali sebagai asam amino tirosin. Akibatnya, tubuh akan defisien asam amino tirosin dan produksi 
hormon-hormon tiroksin seperti hormone T3 dan T4 menjadi terganggu (Suharti et al., 2018).

Mimosin daun lamtoro dapat menimbulkan keracunan atau gangguan kesehatan apabila dikonsumsi dalam jumlah banyak dan terus menerus dalam jangka waktu yang lama. Ternak ruminansia yang mengkonsumsi mimosin menunjukkan gejala kehilangan bulu, penurunan konsumsi pakan, menurunkan bobot badan dan menghasilkan performa yang rendah walaupun dipelihara pada pastura yang berkualitas tinggi (Pattanik et al., 2007). Mimosin merupakan senyawa antimitosis akut, menghambat sintesis DNA terutama saat pembelahan sel, dan dapat menyebabkan kerusakan organ internal (Prasad dan Paliwal, 1989). Gejala keracunan mimosin antara lain alopecia, adanya lesi pada oesophagus, kematian fetus dan fertilitas ternak rendah. Secara struktur, mimosin merupakan tyrosin analogue yang dapat menghambat beberapa fungsi enzim seperti tyrosine decarboxylase dan tyrosinase. Penghambatan enzim-enzim tersebut terutama (3+) thymidine folike sel-sel rambut dapat menyebabkan rendahya pertumbuhan bulu dan gejala goitre.

Mimosin yang masuk ke dalam tubuh ternak ruminansia akan cepat didegradasi menjadi 2 isomer dihidroxypiridin yaitu 3,4 dihidroxypiridin (3,4-DHP) dan 2,3 dihidroxypiridin (2,3-DHP) (Halliday et al., 2014). Turunan senyawa mimosin tersebut masih menyebabkan toksik untuk ternak karena kesamaan strukturnya (Puchala et al., 1995, Peixoto et al., 2008, Oppenheim et al., 2000). Pada rumen ternak ruminansia, terdapat bakteri rumen yang mampu mendegradasi mimosin dan dikonversi menjadi 3,4dihydroxypyridine (3,4-DHP) dan hampir $30 \%$ degradasi mimosin terjadi saat awal proses mastikasi. Meskipun mimosin sudah didegradasi menjadi 3,4DHP, namun tidak mengakibatkan detoksifikasi racun mimosin. Penelitian sebelumnya menunjukkan bahwa terdapat bakteri rumen obligat anaerob gram negatif yaitu Synergistes jonessi yang mampu mendegradasi 3,4-DHP sehingga menjadi tidak toksik (Jones dan Megarity, 1986). Namun demikian, S. jonessi tidak mampu mendegradasi senyawa turunan lain dari mimosian yaitu 2,3-DHP yang juga masih bersifat toksik. Menariknya, pada ternak sapi pedaging di Sumbawa yang mengkonsumsi daun lamtoro dalam jangka panjang menunjukkan konsentrasi 2,3-DHP yang tinggi pada urin namun tidak menunjukkan indikasi goitre (Phaikaew et al., 2012; Halliday et al., 2013). Hal ini mengindikasikan bahwa pada ternak tersebut terdapat bakteri lain yang mampu mendegradasi 2,3-DHP sehingga tidak bersifat toksik pada ternak. Dengan demikian perlu dilakukan kajian yang komprehensif untuk mengisolasi dan mengidentifikasi bakteri pendegradasi senyawa turunan mimosin 2,3-DHP sehingga dapat dikembangkan menjadi inokulum komersial.

Penelitian ini bertujuan untuk melakukan isolasi, identifikasi dan karakterisasi bakteri pendegradasi mimosin dan pengaruh inokulasi bakteri pendegradasi mimosin pada karakteristik fermentasi rumen secara in vitro.

\section{MATERI DAN METODE}

\section{Isolasi dan Karakterisasi Bakteri Pendegradasi Mimosin}

Sumber cairan rumen untuk isolasi bakteri pendegradasi mimosin diambil dari domba dipelihara dengan pakan mengandung tepung daun lamtoro 30\% dan sapi Bali di Sumbawa yang diberi pakan $100 \%$ daun lamtoro segar. Pengambilan cairan rumen dengan menggunakan stomach tube dan segera setelah itu disimpan dalam media gliserol. Isolasi bakteri pendegradasi mimosin dilakukan dengan menggunakan media selektif yang mengandung mimosin (3,7 $\mathrm{g}$ BHI,0,05 g glukosa, $0.05 \mathrm{~g}$ pati, $0.1 \mathrm{~g}$ sistein, $1 \mathrm{ml} \mathrm{CMC}$ $1 \%, 0.5 \mathrm{ml}$ hemin dan $0.05 \mathrm{ml}$ resazurin $/ 100 \mathrm{ml}$ aquades dan mimosin setara $1000 \mathrm{ppm}$ ).

Tahap pertama proses isolasi adalah pengayaan mikroba rumen dengan media selektif selama 5 hari untuk seleksi bakteri yang mampu mendegradasi mimosin (Ilham et al., 2015).

Tahap kedua adalah pemurnian bakteri pendegradasi mimosin dengan menumbuhkan koloni terpilih pada media BHI yang ditambah mimosin selama 24 jam menggunakan shaker water bath pada suhu $39^{\circ} \mathrm{C}$ Untuk dilakukan koloni yang ragam, dilakukan dengan pengenceran serial sampai pengenceran $10^{-10}$.

Tahap ketiga adalah karakterisasi isolat bakteri terpilih meliputi pewarnaan gram, uji motilitas dan uji gula sederhana. Pewarnaan gram dilakukan untuk mengidentifikasi bakteri gram positif dan gram negatif dengan teknik pewarnaan krital violet dan sapranin (Ogimoto dan Imai, 1980). Uji motilitas ini dilakukan untuk mengamati pergerakan bakteri (Jenie dan Ferdiaz, 1989). Uji gula sederhana dilakukan untuk menganalisis kemampuan bakteri mereduksi gula sederhana yaitu glukosa, fruktosa, selulosa, sukrosa dan pati (Dwidjoseputro, 1998).

Variabel yang diukur pada tahap ini adalah karakteristik morfologi isolat yang meliputi pewarnaan gram, bentuk, motilitas dan kemampuan mereduksi gula sederhana.

\section{Inokulasi Bakteri Pendegradasi Mimosin pada Fermentasi Rumen In Vitro}

Percobaan ini dilakukan untuk menganalisis kemampuan bakteri pendegradasi mimosin pada ransum yang mengandung tepung daun lamtoro secara in vitro. Cairan rumen sebagai media in vitro berasal dari sapi Peranakan Ongol berfistula dengan nomor ACUC (Ethical Approval dari Animal Care and Use Committee) IPB 01-2013 IPB yang ada di LIPI Cibinong Bogor. Cairan dan fraksi pakan dari rumen dimasukkan ke dalam termos yang dengan suhu 39-40 ${ }^{\circ} \mathrm{C}$, kemudian disaring dengan double chessecloth untuk fermentasi in vitro. Fermentasi in vitro dilakukan menurut prosedur Tilley dan Terry (1963) dengan 
komposisi media $10 \mathrm{ml}$ cairan rumen, $40 \mathrm{ml}$ larutan Mc. Dougal dan $0.5 \mathrm{~g}$ substrat. Media fermentasi in vitro dimasukkan ke dalam tabung fermentor dengan kondisi anaerob dan diinkubasi ke dalam shaker water bath dengan suhu $39^{\circ} \mathrm{C}$ selama 4 dan 48 jam.

Rancangan yang digunakan pada percobaan in vitro adalah rancangan acak kelompok pola faktorial dengan 2 faktor. Pengelompokan berdasarkan waktu pengambilan cairan rumen. Faktor pertama terdiri dari 3 taraf daun lamtoro yaitu 0, 30 dan $60 \%$ dalam ransum. Faktor kedua terdiri dari 2 inokulasi pendegradasi mimosin yaitu dengan dan tanpa inokulasi bakteri pendegradasi mimosin. Komposisi ransum perlakuan disajikan pada Tabel 1. Komposisi nutrien ransum setiap perlakuan disajikan pada Tabel 2.

Variabel yang diukur pada tahap in vitro ini adalah nilai $\mathrm{pH}$ rumen, populasi mikroba rumen (protozoa dan bakteri), konsentrasi amonia $\left(\mathrm{NH}_{3}\right)$, produksi VFA total, kecernaan bahan kering dan bahan organik.

\section{Pengambilan Sampel dan Pengukuran}

Setelah inkubasi 4 jam, sampel cairan rumen diambil untuk analisis $\mathrm{pH}$ rumen, populasi protozoa, populasi bakteri, produksi VFA dan konsentrasi $\mathrm{NH}_{3}$. Nilai kecernaan bahan kering dan bahan organik diukur setelah 48 jam inkubasi dengan penambahan enzim pepsin pada tabung fermentor.

Pengukuran nilai $\mathrm{pH}$ dilakukan dengan menggunakan $\mathrm{pH}$ meter yang sudah distandarisasi pada larutan buffer $\mathrm{pH} 4$ dan 7 . Analisis $\mathrm{NH}_{3}$ dilakukan dengan menggunakan metode Mikrodifusi Conway (Conway, 1962). Produksi VFA total diukur dengan teknik 'steam destilation' (General Laboratory Procedure, 1966). Populasi protozoa dihitung dengan

Tabel 1. Formula ransum sebagai substrat fermentasi in vitro (dalam bahan kering)

\begin{tabular}{lccc}
\hline \multirow{2}{*}{ Bahan Baku } & \multicolumn{3}{c}{ Perlakuan Taraf Tepung Daun } \\
& \multicolumn{3}{c}{ Lamtoro } \\
\cline { 2 - 4 } & P1 & P2 & P3 \\
\hline Rumput Gajah (RG) & 60 & 30 & 0 \\
Lamtoro & 0 & 30 & 60 \\
Konsentrat : & & & \\
- Bungkil kedelai & 6 & & \\
- Pollard & 33 & 20 & 39 \\
- Onggok & & 19 & \\
- CaCO3 & 1 & 1 & 1 \\
- DCP & & & \\
\hline
\end{tabular}

Tabel 3. Kadar mimosin sampel pengayaan mikroba cairan rumen domba konsumsi $30 \%$ daun lamtoro setelah inkubasi 24 jam

\begin{tabular}{lccc}
\hline \hline Hari ke- & $\begin{array}{c}\text { Mimosin } \\
\text { Awal }(\mathrm{ppm})\end{array}$ & $\begin{array}{c}\text { Mimosin 24 jam } \\
(\mathrm{ppm})\end{array}$ & $\begin{array}{c}\text { Penurunan } \\
\text { Mimosin }(\%)\end{array}$ \\
\hline 1 & 133,14 & 124,57 & 6,44 \\
2 & 133,14 & 116,00 & 12,88 \\
3 & 133,14 & 111,71 & 16,09 \\
4 & 138,86 & 124,57 & 10,29 \\
5 & 151,71 & 140,29 & 7,53 \\
\hline Rerata & $138 \pm 8,05$ & $123,43 \pm 10,95$ & $10,65 \pm 3,94$ \\
\hline
\end{tabular}

menggunakan Fuchs Rosenthal Counting Chamber dan populasi bakteri dengan menggunakan metode roller tube (Ogimoto dan Imai, 1981). Nilai kecernaan bahan kering dan bahan organik dianalisis dengan menggunakan prosedur Tilley dan Terry (1963).

\section{Analisis Data}

Data yang diperoleh dari tahap isolasi dianalisis secara deskriptif. Data karakteristik fermentasi in vitro dianalisis dengan Analysis of Variance (ANOVA) dan apabila ada perbedaan yang nyata antar perlakuan dilanjutkan dengan uji Duncan Multiple Range Test dengan menggunakan program SPSS ver 16.

\section{HASIL DAN PEMBAHASAN}

\section{Kemampuan Degradasi Mimosin Tahap Pengayaan Isolat}

Pada tahap pengayaan isolat selama 5 hari asal rumen domba dengan media selektif mengandung mimosin, terdapat kecenderungan isolat yang diperoleh mempunyai kemampuan mendegradasi mimosin antara $6,44 \%-16,09 \%$ dengan rata-rata $10,65 \%$ (Tabel 3).

Terdapat kecenderungan peningkatan persentase penurunan mimosin sampai hari ke 3 , namun mulai menurun sampai hari ke 5 (Tabel 4). Perubahan penurunan kadar mimosin ini mungkin disebabkan karena penurunan kemampuan isolat mendegradasi mimosin dalam sistem in vitro. Hal ini dimungkinan karena semakin lama maka nutrien yang tersedia dalam media in vitro juga semakin berkurang. Rendahnya rata-rata mimosin yang bisa didegradasi oleh isolat bakteri juga mengindikasikan bahwa populasi bakteri pendegradasi mimosin yang ada dalam cairan rumen

Tabel 2. Kandungan nutrien ransum penelitian (dalam bahan kering)

\begin{tabular}{lccc}
\hline \hline \multirow{2}{*}{ Komponen (\%) } & \multicolumn{3}{c}{ Perlakuan Taraf Tepung Daun } \\
& Pamtoro \\
\cline { 2 - 4 } & P1 & P2 & P3 \\
\hline Bahan Kering (BK) & 47,00 & 49,00 & 51,00 \\
Abu & 11,00 & 8,00 & 6,00 \\
Protein Kasar (PK) & 14.03 & 14,40 & 16,42 \\
Lemak Kasar (LK) & 19,00 & 13,00 & 4,00 \\
Serat Kasar (SK) & 23,00 & 19,00 & 14,00 \\
BetaN & 32,00 & 46,00 & 61,00 \\
TDN & 66,24 & 69,88 & 73,14 \\
Ca & 0,77 & 0,98 & 1,00 \\
P & 0,51 & 0,33 & 0,30 \\
\hline Keteragan : P1 = 60\% RG + 0\% lamtoro + 40\% konsentrat; P2= 30\% RG +
\end{tabular}

$30 \%$ lamtoro $+40 \%$ konsentrat; $\mathrm{P} 3=0 \% \mathrm{RG}+60 \%$ lamtoro $+40 \%$ konsentrat

Tabel 4. Kemampuan degradasi mimosin setelah inkubasi 24 jam oleh isolat bakteri asal cairan rumen Sapi di Sumbawa dengan ransum $100 \%$ daun Lamtoro

\begin{tabular}{lccc}
\hline \hline Isolat & $\begin{array}{c}\text { Mimosin } \\
\text { Awal }(\mathrm{ppm})\end{array}$ & $\begin{array}{c}\text { Mimosin 24 } \\
\mathrm{Jam}(\mathrm{ppm})\end{array}$ & $\begin{array}{c}\text { Penurunan } \\
\text { Mimosin }(\%)\end{array}$ \\
\hline Kontrol & $95,71 \pm 4,04$ & $95,00 \pm 3,03$ & $0,72 \pm 1,02$ \\
Isolat 1 & $113,57 \pm 3,03$ & $97,14 \pm 0,00$ & $14,43 \pm 2,28$ \\
Isolat 2 & $116,43 \pm 7,07$ & $95,71 \pm 0,00$ & $17,64 \pm 5,00$ \\
Isolat 3 & $109,29 \pm 5,05$ & $96,43 \pm 1,01$ & $11,65 \pm 5,01$ \\
\hline
\end{tabular}


domba yang mengonsumsi 30\% daun lamtoro masih sangat sedikit. Domba yang diambil cairan rumennya ini baru 3 bulan mengkonsumsi lamtoro sebesar $30 \%$ dari total ransum sehingga bakteri pendegradasi mimosin belum tumbuh secara optimal. Mikroba rumen perlu beradaptasi dalam jangka panjang dengan jenis pakan baru yang mengandung senyawa antinutrisi (Hobson dan Steawart, 1997).

Pola yang sama juga terdapat pada isolat bakteri yang diperoleh dari rumen sapi di Sumbawa yang mendapat ransum $100 \%$ daun lamtoro segar. Persentase penurunan mimosin dengan penambahan isolat 1 , isolat 2 dan isolat 3 berikisar antara 11,65-17,64\% (Tabel 4).

Ternak ruminansia yang terus menerus diberi bahan pakan mengandung antinutrisi, maka akan mengembangkan mikroflora rumen yang toleran terhadap antinutrisi yang ada dan terus berkembang dalam rumen sehingga terkadang membatasi pertumbuhan beberapa mikroba lain (Kamra, 2005). Hasil penelitian Suharti et al. (2018) menunjukkan adanya mimosin dalam darah domba yang mengkonsumsi lamtoro $30 \%$ yang mengindikasikan bahwa mimosin yang tidak terdegradasi di rumen akan mengalami penyerapan masuk ke dalam pembuluh darah.

\section{Pemurnian Bakteri Pendegradasi Mimosin}

Hasil pemurnian isolat menunjukkan bahwa ditemukan 2 koloni isolat terseleksi yang mampu beradaptasi pada media mengandung mimosin. Isolat 1 berwarna putih susu sedangkan isolat 2 berwarna bening dengan adanya titik putih di tengah (Gambar 1).

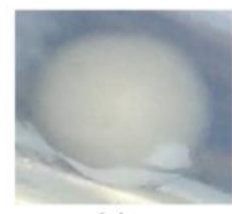

(a)

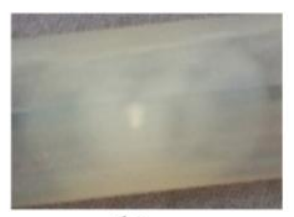

(b)
Gambar 1. Koloni isolat bakteri penderadasi mimosin asal rumen domba yang mengkonsumsi lamtoro $30 \%$ : (a) Isolat 1; (b) Isolat 2
Pada cairan rumen sapi dari Sumbawa yang mengonsumsi $100 \%$ daun lamtoro segar ditemukan 3 koloni isolat yang mampu beradaptasi pada media mengandung mimosin. Isolat 1 mempunyai karakteristik berwarna putih susu dengan bentuk koloni bulat, isolat 2 berwarna putih bening dengan koloni lonjong dan isolat 3 berwarna putih bening dengan koloni bulat dan mempunyai titik putih di tengah (Gambar 2).

\section{Karakterisasi Isolat Bakteri Terpilih}

Berdasarkan uji morfologi, pewarnaan gram dan uji gula-gula pereduksi, baik 2 isolat yang diperoleh dari rumen domba dengan pakan tepung daun lamtoro $30 \%$ maupun 3 isolat dari rumen sapi di Sumbawa dengan pakan $100 \%$ daun lamtoro segar mempunyai karakteristik yang hampir sama. Karakteristik kelima isolat tersebut merupakan gram positif, suhu pertumbuhan $39^{\circ} \mathrm{C}$ tidak motil, bersifat fakultatif anaerob dan mampu memanfaatkan gula-gula sederhana yaitu glukosa, sukrosa, fruktosa, pati dan selulosa (Tabel 5).

Isolat yang ditemukan bersifat fakultatif anaerob yang bisa hidup pada lingkungan anaerob dan aerob. Karakter ini sangat menguntungkan untuk diaplikasikan sebagai probiotik pada ruminansia mengingat kondisi rumen itu anaerob. Karena juga

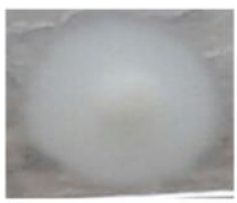

(a)

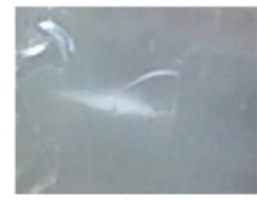

(b)

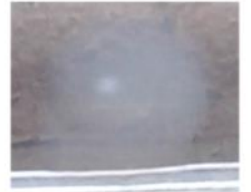

(c)

Gambar 2. Koloni isolat bakteri penderadasi mimosin asal rumen sapi dari Sumbawa yang mengonsumsi $100 \%$ daun lamtoro : Isolat 1; (b) Isolat 2; (c) Isolat 3

Tabel 5. Karakterisasi isolat bakteri cairan rumen ternak yang mengonsumsi pakan daun lamtoro

\begin{tabular}{|c|c|c|c|c|c|}
\hline \multirow{3}{*}{ Peubah } & \multicolumn{5}{|c|}{ Cairan rumen } \\
\hline & \multicolumn{2}{|r|}{ Domba } & \multicolumn{3}{|c|}{ Sapi } \\
\hline & Isolat 1 & Isolat 2 & Isolat 1 & Isolat 2 & Isolat 3 \\
\hline Warna koloni & Putih & $\begin{array}{c}\text { Putih dengan bening } \\
\text { disekitarnya }\end{array}$ & Putih & $\begin{array}{l}\text { Putih dengan bening } \\
\text { disekitarnya }\end{array}$ & $\begin{array}{l}\text { Titik putih dengan } \\
\text { bening disekitarnya }\end{array}$ \\
\hline Bentuk koloni & Bulat & Bulat & Bulat & Lonjong & Bulat \\
\hline Bentuk sel & Bulat & Bulat & Bulat & Lonjong & Bulat \\
\hline Pewarnaan gram & + & + & + & + & + \\
\hline Motilitas & - & - & - & - & - \\
\hline Suhu tumbuh $\left({ }^{\circ} \mathrm{C}\right)$ & 39 & 39 & 39 & 39 & 39 \\
\hline Fakultatif anaerob & + & + & + & + & + \\
\hline $\begin{array}{l}\text { Pemanfaatan } \\
\text { karbohidrat }\end{array}$ & & & & & \\
\hline - Glukosa & + & ++ & ++ & ++ & ++ \\
\hline - $\quad$ Sukrosa & + & ++ & ++ & ++ & ++ \\
\hline - Fruktosa & ++ & + & ++ & ++ & ++ \\
\hline - $\quad$ Pati & ++ & ++ & ++ & ++ & ++ \\
\hline - Selulosa & ++ & ++ & ++ & ++ & ++ \\
\hline
\end{tabular}


mempunyai sifat aerob, maka akan memudahkan saat penanganan kultur tersebut pada kondisi rumen. Kemampuan mereduksi semua gula-gula sederhana yang diuji juga menunjukkan bahwa isolat yang diperoleh mampu memanfaatkan karbohidrat pakan. Semakin banyak karbohidrat yang bisa direduksi, maka semakin tinggi kemampuan daya hidup dalam lingkungan rumen.

Beradasarkan karakteristik morfologi dan pewarnaan gram, isolat yang ditemukan berbeda dengan karakteristik bakteri $S$. jonesii yang memiliki bentuk batang oval, gram negatif serta tidak mempunyai flagela dan spora (Allison et al., 1992). Derakhshani et al. (2015) menyatakan bahwa ada beberapa bakteri lain yang mempunyai kemampuan mendegrdasi mimosin yaitu Butyrivibrio fibrisolvens, Colostridium butyricum, Lactobacillus vitulinus dan Streptococcus lutetiensis.

Dari hasil karakterisasi isolat bakteri yang diperoleh baik dari rumen domba dengan ransum $30 \%$ tepung daun lamtoro, maupun dari rumen sapi di Sumbawa yang mendapat ransum $100 \%$ daun lamtoro segar menunjukkan bahwa isolat tersebut mempunyai kemiripan dengan Streptococcus sp.

\section{Pengaruh Inokulasi Bakteri Pendegradasi Mimosin pada Karakteristik Fermentasi Rumen secara In Vitro \\ Populasi Mikroba Rumen}

Tidak ada interaksi antara pemberian berbagai taraf pemberian daun lamtoro dengan inokulasi isolat bakteri pendegradasi mimosin pada populasi mikroba rumen yaitu total protozoa dan bakteri. Populasi total protozoa dan bakteri rumen relatif sama dengan pemberian berbagai taraf tepung daun lamtoro. Pemberian isolat bakteri pendegradasi mimosin juga tidak -memberikan pengaruh pada populasi total protozoa dan bakteri (Tabel 6).

Tidak adanya perubahan populasi protozoa dan bakteri rumen dengan pemberian tepung daun lamtoro sampai taraf $60 \%$ menunjukkan bahwa kandungan antinutrisi yang ada pada daun lamtoro tidak mengganggu pertumbuhan bakteri maupun protozoa. Daun lamtoro selain mengandung antinutrisi mimosin, juga mengandung tannin terkondensasi dan saponin
(Zarin et al., 2016). Namun demikian, kandungan tannin dan saponin pada daun lamtoro belum menghambat pertumbuhan bakteri maupun protozoa.

Inokulasi isolat bakteri pendegradasi mimosin juga tidak berkompetisi dengan mikroba rumen yang sudah ada sehingga tidak memberikan pengaruh pada populasi protozoa dan bakteri rumen. Astuti et al. (2018) menyatakan bahwa penambahan bakteri lain ke dalam ekosistem rumen sangat jarang menyebabkan perubahan signifikan pada populasi bakteri total. Hasil yang berbeda disampaikan oleh Galindo (2007) yang menyatakan bahwa pemberian daun lamtoro pada ternak yang dipelihara pada padang penggembalaan menurunkan populasi protozoa dan memperbaiki komposisi mikroba rumen. Barros-Rodríguez et al. (2015) juga melaporkan bahwa penggunaan daun lamtoro (L. leucochepala) sampai taraf $40 \%$ menurunkan populasi protozoa.

\section{Karakteristik Fermentasi Rumen In Vitro}

Tidak ada interaksi antara pemberian berbagai taraf tepung daun lamtoro dengan inokulasi bakteri pendegradasi mimosin pada karakteristik fermentasi rumen yang diamati. Pemberian tepung daun lamtoro sampai taraf $60 \%$ nyata menurunkan $(\mathrm{p}<0.05)$ konsentrasi $\mathrm{NH}_{3}$ dan VFA total, namun tidak memberikan pengaruh pada $\mathrm{pH}$ rumen serta kecernaan bahan kering dan bahan organik (KcBK dan $\mathrm{KcBO}$ ). Inokulasi bakteri bakteri pendegradasi mimosin mampu meningkatkan $(\mathrm{p}<0,05)$ konsentrasi $\mathrm{NH}_{3}$ dan cenderung memperbaiki VFA total dibandingkan dengan yang tidak diinokulasi bakteri pendegradasi mimosin (Tabel 7).

Nilai $\mathrm{pH}$ yang relatif sama antar perlakuan dan berada pada kisaran normal yaitu nilai $\mathrm{pH} 7$ (McDonald, 2002) menunjukkan bahwa lingkungan rumen masih stabil dengan pemberian tepung daun lamtoro sampai taraf $60 \%$ baik yang diinokulasi dengan bakteri pendengradasi mimosin maupun tanpa inokulasi. Nilai $\mathrm{pH}$ yang stabil ini mengindikasikan kondisi rumen yang optimal untuk mikroba rumen dalam proses degradasi dan fermentasi pakan.

Penurunan konsentrasi $\mathrm{NH}_{3}$ dengan penggunaan tepung daun lamtoro sampai taraf $60 \%$ tanpa inokulasi bakteri diduga karena adanya kandungan tanin pada

Tabel 6. Populasi mikroba rumen in vitro dengan penggunaan isolat bakteri pendegradasi mimosin dan tepung daun lamtoro pada taraf yang berbeda

\begin{tabular}{llccc}
\hline \multirow{2}{*}{ Peubah } & \multirow{2}{*}{ Perlakuan Ransum } & Tanpa Isolat & Dengan Isolat & \multirow{2}{*}{ Rerata \pm SD } \\
\cline { 3 - 4 } & & $4,78 \pm 0,66$ & $4,55 \pm 0,25$ & $4,67 \pm 0,20$ \\
Populasi & 0\% Lamtoro & $4,62 \pm 0,13$ & $4,36 \pm 0,31$ & $4,49 \pm 0,25$ \\
Protozoa & 30\% Lamtoro & $4,33 \pm 0,25$ & $4,46 \pm 0,36$ & $4,39 \pm 0,29$ \\
\hline (log sel/ml) & 60\% Lamtoro & $4,58 \pm 0,24$ & $4,45 \pm 0,28$ & \\
\hline & Rerata \pm SD & $6,23 \pm 0,31$ & $6,16 \pm 0,56$ & $6,20 \pm 0,20$ \\
Populasi Bakteri & 0\% Lamtoro & $5,62 \pm 0,97$ & $6,73 \pm 0,11$ & $6,17 \pm 0,87$ \\
$(\log$ CFU/ml) & 30\% Lamtoro & $6,91 \pm 1,07$ & $6,87 \pm 0,68$ & $6,89 \pm 0,68$ \\
\hline & 60\% Lamtoro & $6,25 \pm 0,93$ & $6,59 \pm 0,33$ & \\
\hline
\end{tabular}


daun lamtoro yang seringkali mengikat protein pakan dan menyulitkan degradasinya oleh mikroba rumen. Akibatnya menurunkan konsentrasi $\mathrm{NH}_{3}$ di rumen karena produk akhir dari degradasi protein pakan oleh mikroba rumen adalah $\mathrm{NH}_{3}$ (Siddons dan Paradine, 1983). Sebaliknya, inokulasi bakteri pendegradasi mimosin mampu meningkatkan konsentrasi $\mathrm{NH}_{3}$ yang mengindikasikan bahwa terjadi degradasi protein yang lebih tinggi. Hal ini di duga isolat bakteri pendegradasi mimosin yang ditemukan juga merupakan bakteri proteolitik sehingga protein daun lamtoro yang sangat tinggi (sekitar 24\%) bisa didegradasi dengan optimal dalam rumen.

Selain itu, inokulasi bakteri pendegradasi mimosin juga berperan meningkatkan penguraian struktur mimosin daun lamtoro dan menyebabkan gugus aminonya terdeaminasi membentuk $\mathrm{NH}_{3}$ Konsentrasi $\mathrm{NH}_{3}$ yang cukup memungkin terjadinya sintesis protein mikroba dengan optimal karena $\mathrm{NH}_{3}$ merupakan salah satu senyawa prekursor dalam sintesis protein mikroba (McDonald, 2002).

Penurunan produksi VFA dengan pemberian tepung daun lamtoro sampai $60 \%$ tanpa inokulasi bakteri mengindikasikan terganggunya proses fermentasi pakan oleh mikroba rumen. Hal ini diduga karena adanya senyawa antinutrisi lain dalam daun lamtoro. Tan et al. (2011) melaporkan adanya penurunan total VFA dengan penambahan tanin daun lamtoro. Tanin juga berikatan dengan zat nutrisi lain seperti karbohidrat, mineral dan vitamin. Selain itu, tannin juga dapat mengikat kompleks lignoselulosa sehingga menurunkan pencernaan serat atau langsung menghambat kerja bakteri selulolitik (Sweeney et al.,
2001). Inokulasi bakteri pendegradasi mimosin dapat memperbaiki produksi total VFA yang menunjukkan bahwa isolat bakteri yang diinokulasikan mampu menstimulasi proses fermentasi pakan dalam rumen. Selain itu, peningkatan produksi VFA pada perlakuan inokulasi isolat bakteri pendegradasi mimosin juga berkaitan dengan degradasi protein yang meningkat. Protein pakan terdegradasi menjadi asam amino dan selanjutnya dideaminasi menjadi $\mathrm{NH}_{3}$ dan asam $\alpha$ keto. Asam $\alpha$ keto diubah iso butirat, iso valerat dan 2 metil butirat yang merupakan komponen senyawa VFA (Widodo et al., 2012).

Kesamaan nilai KcBK dan KcBO dengan pemberian berbagai taraf tepung daun lamtoro sampai taraf $60 \%$ baik yang diinokulasi dengan bakteri pendegradasi mimosin maupun dengan yang tidak diinokulasi menunjukkan tidak adanya gangguan kecernaan bahan kering maupun bahan organik. Hal yang sama dilaporkan oleh Piñeiro-Vázquez et al. (2017) yang menyatakan bahwa tidak ada perbedaan kecernaan bahan kering dan kecernaan bahan organik dengan pemberian daun lamtoro.

\section{KESIMPULAN}

Ditemukan 2 isolat bakteri pendegradasi mimosin dari rumen domba dan 3 isolat rumen sapi Bali. Kelima isolat tersebut mempunyai kemiripan dengan Streptococcus sp. Hasil uji in vitro menunjukkan bahwa tidak ada interaksi antara taraf pemberian daun lamtoro dengan inokulasi bakteri pendegradasi mimosin pada fermentasi rumen. Inokulasi bakteri pendegradasi mimosin dapat meningkatkan konsentrasi

Tabel 7. Karakteristik fermentasi rumen in vitro dengan penggunaan isolat bakteri pendegradasi mimosin dan tepung daun lamtoro pada taraf yang berbeda

\begin{tabular}{llccc}
\hline \hline \multirow{2}{*}{ Peubah } & \multirow{2}{*}{ Perlakuan Ransum } & \multicolumn{2}{c}{ Pemberian Isolat } & \multirow{2}{*}{ Rerata \pm SD } \\
\cline { 2 - 3 } Nilai pH & 0\% Lamtoro & $7,1 \pm 0,00$ & $7,06 \pm 0,05$ & $7,08 \pm 0,04$ \\
& 30\% Lamtoro & $7,06 \pm 0,05$ & $7,03 \pm 0,05$ & $7,05 \pm 0,05$ \\
& 60\% Lamtoro & $7,06 \pm 0,05$ & $7,00 \pm 0,00$ & $7,03 \pm 0,05$ \\
\hline \multirow{3}{*}{$\mathrm{NH}_{3}(\mathrm{mM})$} & Rataan \pm SD & $7,07 \pm 0,04$ & $7,03 \pm 0,05$ & \\
& 0\% Lamtoro & $9,12 \pm 1,32$ & $11,99 \pm 2,24$ & $10,56 \pm 2,27^{\mathrm{a}}$ \\
& 30\% Lamtoro & $5,60 \pm 1,74$ & $8,08 \pm 1,02$ & $6,84 \pm 1,86^{\mathrm{b}}$ \\
& 60\% Lamtoro & $5,11 \pm 2,27$ & $7,84 \pm 1,83$ & $6,48 \pm 2,37^{\mathrm{b}}$ \\
\hline \multirow{3}{*}{$\mathrm{VFA}(\mathrm{mM})$} & Rataan \pm SD & $6,61 \pm 2,46^{\mathrm{a}}$ & $9,30 \pm 2,53^{\mathrm{b}}$ & \\
& 0\% Lamtoro & $96,39 \pm 25,98$ & $115,26 \pm 41,02$ & $105,82 \pm 32,40^{\mathrm{a}}$ \\
& 30\% Lamtoro & $67,76 \pm 29,28$ & $67,80 \pm 5,67$ & $67,78 \pm 18,86^{\mathrm{b}}$ \\
& 60\% Lamtoro & $52,48 \pm 6,50$ & $65,61 \pm 17,20$ & $59,04 \pm 13,67^{\mathrm{b}}$ \\
\hline \multirow{3}{*}{ KcBK $(\%)$} & Rataan \pm SD & $72,21 \pm 27,68$ & $82,89 \pm 33,05$ & \\
& 0\% Lamtoro & $70,81 \pm 5,75$ & $70,02 \pm 2,70$ & $70,42 \pm 4,04$ \\
& 30\% Lamtoro & $70,32 \pm 3,14$ & $69,96 \pm 2,83$ & $70,14 \pm 2,68$ \\
\hline & 6\% Lamtoro & $70,54 \pm 1,89$ & $70,69 \pm 3,31$ & $70,62 \pm 2,41$ \\
\hline \multirow{2}{*}{ KcBO $(\%)$} & Rataan \pm SD & $70,56 \pm 3,41$ & $70,22 \pm 2,59$ & \\
\hline & 0\% Lamtoro & $69,46 \pm 4,97$ & $67,43 \pm 3,26$ & $68,44 \pm 3,92$ \\
& 30\% Lamtoro & $68,56 \pm 2,69$ & $68,14 \pm 2,00$ & $68,35 \pm 2,13$ \\
\hline
\end{tabular}

$\overline{\mathrm{a}, \mathrm{b}}$ Superskrip yang berbeda pada kolom dan baris yang sama menunjukkan berbeda nyata $(\mathrm{p}<0,05), \mathrm{VFA}=$ volatile fatty acid, KcBK=kecernaan bahan kering, $\mathrm{KcBO}=$ kecernaan bahan organik 
$\mathrm{NH}_{3}$ dan cenderung memperbaiki produksi VFA dibandingkan dengan perlakuan tanpa inokulasi bakteri. Nilai pH, KcBK dan KcBO tidak berbeda antar perlakuan. Inokulasi bakteri pendegradasi mimosin dapat menstimulasi fermentasi rumen secara in vitro.

\section{UCAPAN TERIMA KASIH}

Tim penulis mengucapkan terimakasih yang setinggi-tingginya kepada Direktorat Jenderal Pendidikan Tinggi, Kementrian Riset, Teknologi dan Pendidikan Tinggi Republik Indonesia yang sudah mendanai penelitian ini melalui hibah Kerjasama Luar Negeri dan Publikasi Internasional (KLN) dengan nomor kontrak: 011/SP2H/LT/DRPM/IV/2017 tanggal 20 April 2017 dan hibah Addendum dengan nomor kontrak: 011/SP2H/LT/DRPM/VIII/2017 tanggal 21 Agustus 2017.

\section{DAFTAR PUSTAKA}

Allison, M.J., W.R. Mayberry, C.S. McSweeney and D.A. Stahl. 1992. Synergistes jonesii, gen. nov. sp. nov: a rumen bacterium that degrades toxic pyridinediols. Systemic and Applied Microbiology 15: 522-529.

Astuti, W.D., K.G. Wiryawan, E. Wina, Y. Widyastuti, S. Suharti and R. Ridwan. 2018. Effects of selected Lactobacillus plantarum as probiotic on In vitro ruminal fermentation and microbial population. Pakistan Journal of Nutrition 17: 131-139.

Barros-Rodríguez, M.A., F.J. Solorio-Sánchez, C.A. Sandoval-Castro, A. Klieve, R.A. RojasHerrera, E.G. Briceño-Poot, and J.C. Ku-Vera. 2015. Rumen function in vivo and in vitro in sheep fed Leucaena leucocephala. Tropical Animal Health Production 47: 757-764.

Conway, E.J. 1962. Microdiffusion Analysis and Volumetric Error. 5th revised edition, Crosby Lockwood and Son Ltd., London

D’Mello, J.P.F. 2000. Farm Animal Metabolism and Nutrition. CABI Publ. Wallingford, UK.

Derakhshani, H., W. Sean, Corley and R. Al Jassim. 2016. Isolation and characterization of mimosine, 3. 4 DHP and 2. 3 DHP degrading bacteria from a commercial rumen inoculum. Journal of Basic Microbiology 56: 580-585.

Dwidjoseputro, D. 1998. Dasar-Dasar Mikrobiologi. Djambatan. Jakarta

Galindo J, C. García, Y. Marrero, E. Castillo, A.I. Aldana, V. Torres and L. Sarduy. 2007. Effect of the composition of a grassland of Lecucaena leucocephala with grasses on the microbial rumen population of bulls. Cuban Journal of Agricultural Science 41(2):137-140.

General Laboratory Procedures. 1966. Department of Dairy Science. University of Wisconsin. Madison.
Ghosh, M.K. and S. Bandyopadhyay. 2007. Mimosine toxicity-a problem of leucaena feeding in ruminants. Asian Journal of Animal and Veterinary Advances 2(2): 63-73.

Halliday, MJ., J. Padmanabha, C.S. Mcsweeney, G. Kerven and H.M. Shelton. 2013. Leucaena toxicity: a new perspective on the most widely used forage tree legume. Tropical grasslandsForrages Tropicales 1: 1-11.

Halliday, M.J., T. Panjaitan, J. Nulik, Dahlanuddin, J. Padmanabha, C.S. Mcsweeney, S. Depamede, D.K. Hau, Kurniawan, M. Fauzan, Sutartha, B.T. Yuliana, C. Pakereng, P. Ara, D. Liubana, R.G. Edison and H.M. Shelton. 2014. Prevalence of DHP toxicity and detection of Synergistes jonesii in ruminants consuming Leucaena leucocephala in eastern Indonesia. Tropical Grasslands-Forrages Tropicales 2: 7173.

Hobson, P.N. and C.S. Stewart. 1997. The Rumen Microbial Ecosystem. Blackie Academic \& Professional. London, UK.

Ilham, Z., H. Hamidon, N.A. Rosji, N. Ramli and Osman. 2015. Extraction and quantification of toxic compound mimosine from Leucaena leucocephala leaves. Procedia Chemistry 16: 164-170.

Jenie, B.S.L. dan S. Fardiaz. 1989. Uji Sanitasi dalam Industri Pangan. Bogor: Pusat Antar Universitas Pangan dan Gizi, Institut Pertanian Bogor.

Jones RJ, Megarrity RG. 1986. Successful transfer of DHP-degrading bacteria from Hawaiian goats to Australian ruminants to overcome the toxicity of Leucaena. Australian Veterinary Journal 63: 259-262.

Kamra, D.N. 2005. Rumen microbial ecosystem. Current Science 89(1): 124-135.

McDonald, P., R.A. Edward, J.F.D. Greenhalgh, C.A. Morgan, L.A. Sinclair and R.G. Wilkinson. 2002. Animal Nutrition. $8^{\text {th }}$ Edition.: Longman London. New York.

McSweeney, C.S., B. Palmer, D.M. McNeill and D.O. Krause. 2001. Microbial interactions with tannins: nutritional consequenses for ruminants. Animal Feed Science and Feed Technology 91: 83-93.

Ogimoto, K. and S. Imai. 1981. Atlas of Rumen Microbiology: Japan Sci Societies Pr. Tokyo.

Oppenheim, E.W., I.M. Nasrallah, M.G. Mastri and P.J. Stover. 2000. Mimosine Is a cell-specific antagonist of folate metabolism. Journal of Biological Chemistry 275(25): 19268-19274.

Pattanaik, A.K., S.A. Khan and T.K. Goswami. 2007. Influence of iodine on nutritional, metabolic and immunological response of goats fed Leucaena leucocephala leaf meal diet. Journal of Agricultural Science 145: 395-405.

Peixoto, P.V., T.N. França, B.M. Cunha, D. Valadão, A.M. Tavares and M.F. Brito. 2008. Spontaneous poisoning by Leucaena 
leucocephala in a goat from Rio de Janeiro State. Brazil. Cienc Rural 38(2): 551-555.

Phaikaew, C., W. Suksaran, J. Ted-Arsen, G. Nakamanee, A. Saichuer, S. Seejundee, N. Kotprom and H.M. Shelton. 2012. Incidence of subclinical toxicity in goats and dairy cows consuming leucaena (Leucaena leucocephala) in Thailand. Animal Production Science 52: 283-286.

Piñeiro-Vázquez, A.T., G.O. Jiménez-Ferrer, A.J. Chay-Canul, F. Casanova-Lugo, V.F. DíazEcheverría, A.J. Ayala-Burgos, F.J. SolorioSánchez, C.F. Aguilar-Pérez and J.C. Ku-Vera. 2017. Intake, digestibility, nitrogen balance and energy utilization in heifers fed low-quality forage and Leucaena leucocephala. Animal Feed Science and Feed Technology 228: 194201.

Prasad, J. and O.P. Paliwal. 1989. Pathological changes in experimentally induced leucaena toxicity in lambs. Indian Veterinary Journal. 66: 711-714

Puchala, R., T. Sahlu, J.J. Davis and S.P. Hart. 1995. Influence of mineral supplementation on 2.3dihydroxypyridine toxicity in Angora goats. Animal Feed Science and Feed Technology 55: 253-262.

Siddons, R.C. and J. Paradine. 1983. Protein degradation in the rumen of sheep and cattle. Journal of the Science of Food and Agriculture 34(7): 701-708.

Suharti, S., F.X.S. Kurnia, B. Pambudi and K.G.
Wiryawan. 2018. Fate of mimosine, concentration of blood metabolites and thyroid hormones of sheep fed with leucaena and glyricidia leaf meal. Pakistan Journal of Nutrition 17: 268-273.

Tan, H.Y., C.C. CSieo, N. Abdullah, J.B. Liang, X.D. Huang and Y.W. Ho. 2011. Effects of condensed tannins from Leucaena on methane production, rumen fermentation and populations of methanogens and protozoa in vitro. Animal Feed Science and Feed Technology 169: 185193.

Tilley, J.M.A. and R.A. Terry. 1963. A two stage technique for the in-vitro digestion of forage crops. Grass and Forage Science 18: 104-111.

Widodo, F., Wahyono and Sutrisno. 2012. Kecernaan bahan kering, kecernaan bahan organik, produksi VFA dan NH3 pakan komplit dengan level jerami padi berbeda secara in vitro. Indonesian Journal of Food Technology 1: 1-15.

Zayed, M.Z., M.A. Zaki, F.B. Ahmad, H. Wei-Seng and P. Shek-Ling. 2014. The reduction of mimosine content in Leucaena leucocephala (petai belalang) leaves using ethyl methanesulphonate (EMS). Archives of Applied Science Research 6(4): 124-128.

Zarin, M.A., H.Y. Wan, A. Isha and N. Armania. 2016. Antioxidant, antimicrobial and cytotoxic potential of condensed tannins from Leucaena leucocephala hybrid-Rendang. Food Science and Human Wellness 5(2): 65-75. 